\title{
Biomaterials
}

Biomaterials 23 (2002) 1447-1454

www.elsevier.com/locate/biomaterials

\section{Effect of different Ti-6Al-4V surface treatments on osteoblasts behaviour}

\author{
Ching-Hsin $\mathrm{Ku}^{\mathrm{a}, \mathrm{b}, \mathrm{c}}$, Dominique P. Pioletti ${ }^{\mathrm{a}, \mathrm{c}, *}$, Martin Browne ${ }^{\mathrm{b}}$, Peter J. Gregson ${ }^{\mathrm{b}}$ \\ ${ }^{a}$ Bone Biophysics Group, Orthopaedic Hospital, Lausanne, Switzerland \\ ${ }^{\mathrm{b}}$ Bioengineering Sciences Research Group, School of Engineering Sciences, University of Southampton, Highfield, Southampton SO17 1 BJ, UK \\ ${ }^{\mathrm{c}}$ Biomedical Engineering Laboratory, Swiss Federal Institute of Technology, PSE-Ecublens, 1015 Lausanne, Switzerland
}

Received 10 September 2000; accepted 20 July 2001

\begin{abstract}
The purpose of the present work was to examine the effect of different Ti-6Al-4V surface treatments on osteoblasts behaviour. Previous work in this laboratory has demonstrated that an ageing treatment reduces metal ion release from this alloy compared to standard passivation procedures. In this study, human osteosarcoma MG-63 were used in short-term in vitro tests to assay for cell viability and cell proliferation at 12, 24 and $72 \mathrm{~h}$ while SaOS-2 were used in long-term in vitro tests to assay for osteonectin, osteopontin, osteocalcin gene expression, total protein amount (TP), alkaline phosphatase activity (ALP) and fibronectin production (FN) for 1-4 weeks. Epifluorescence microscopy was used to observe SaOS-2 cell morphology. After 24 h, there was no difference in MG-63 cell viability/proliferation or in SaOS-2 cell morphology between the different surface treatments. For the longterm tests, the aged $\mathrm{Ti}-6 \mathrm{Al}-4 \mathrm{~V}$ induced significantly higher cell proliferation than the control $\mathrm{Ti}-6 \mathrm{Al}-4 \mathrm{~V}$ at $72 \mathrm{~h}$. At week 1 , no difference in the osteonectin, osteopontin, and osteocalcin gene expression was found between samples. The peak of ALP activity appeared earlier at week 2 for the control surface compared with the passivated and aged surfaces. The early increase in ALP activity for the control sample could be a compensatory effect of decreased osteoblasts proliferation. There was no difference in the expression of $\mathrm{FN}$ for the different surface treatments. Our present results showed that the different surface treatments, which induced different metal ion release kinetics and surface properties, influenced the cell proliferation and ALP activity of osteoblast cells. Aluminium ions release kinetics as well as presence of vanadium ions may play a major role in influencing the osteoblasts behaviour in the present study. (C) 2002 Elsevier Science Ltd. All rights reserved.
\end{abstract}

Keywords: Ti-6Al-4V; Surface treatment; Metal ion release; Human osteosarcoma cells; Differentiation; Cell morphology

\section{Introduction}

The interaction between solid surfaces and biological systems are critically important to many areas of medicine, technology and research. In general, only the surface of an implant is in direct contact with the host tissue, and thus this portion of the material plays a central role in determining its biocompatibility. The surface of material can change with time, and is often distinctly different from the bulk properties, because of oxidation and contamination. Although the surface clearly plays an important role in implant/cell interac-

*Corresponding author. Biomedical Engineering Laboratory, Swiss Federal Institute of Technology, PSE-Ecublens, 1015 Lausanne, Switzerland. Tel.: +41-21-693-8341; fax: +41-21-693-8330.

E-mail address: dominique.pioletti@epfl.ch (D.P. Pioletti). tions, the relationships between surfaces of the implant, its reactivity with tissue constituents, and long-term integrity and clinical efficacy are still poorly understood $[1,2]$.

Ti-6Al-4V alloy has become one of the most used biomaterials due to its excellent corrosion resistance, good mechanical properties and low toxicity [3]. Its corrosion resistance is due to the oxide film, which forms spontaneously on exposure to air. However, when the titanium alloy is implanted into a complicated and aggressive physiological in vivo environment, the oxide stability may be affected, resulting in increased metal ion release [4]. Elevated levels of metal ions have been reported in the serum of patients with both well functioning and failed total joint replacements [5]. In addition, aluminium (Al) has well documented toxic effects in the serum or urine of patients who had a total 
hip replacement made of titanium alloy [6]. Several in vitro studies have been carried out with a variety of cell lines to test metal ion toxicity, which is suspected of playing a significant role in cell behaviour. Titanium ions have been shown to influence mineral formation and osteoid nodules in rat calvaria cultures [7]. It has been demonstrated that $\mathrm{Ti}-6 \mathrm{Al}-4 \mathrm{~V}$ ion solution can affect the normal differentiation of bone marrow stromal cells to mature osteoblasts in vitro [8]. Therefore, decreasing the metal ion release could be a method to increase the biocompatibility of Ti alloy.

In our previous work, it has been shown that a simple thermal treatment, ageing in deionised distilled boiling water, improves the dissolution resistance of Ti-6Al-4V alloy compared to conventional passivation treatments [9]. In the present study, the biocompatibility of the aged surface was evaluated in comparison to the control and the passivation treatments. Short- and long-term in vitro tests were performed with two osteoblastic cell corresponding to immature and mature cells. The biocompatibility of the aged titanium alloy was evaluated in vitro with short-term tests assessing cell viability, cell proliferation and cell morphology. Then, quantification of the ageing treatment was performed with long-term in vitro tests quantifying osteonectin, osteopontin, osteocalcin gene expression, FN production, ALP activity and TP amount.

\section{Materials and methods}

\subsection{Ti alloy surface preparations}

Distal sections of forged Ti-6Al-4V alloy femoral stems from the Ti-Mod Freeman hip replacement were supplied by Finsbury Instruments (Leatherhead, Surrey, UK). The hip stems were cut into discs of 4 and $10 \mathrm{~mm}^{2}$ and of $1 \mathrm{~mm}$ thickness. The samples were first wetground with 120,600,1200, 2400 and 4000 grit silicon carbide abrasive paper (Struers, UK) at approximately
$150 \mathrm{rpm}$, then polished with 6,3 and $1 \mu \mathrm{m}$ diamond solution (Microcloth Buehler, UK) on a clean polishing cloth (Microcloth Buehler, UK) and finally with colloidal silica polishing suspension $(0.06 \mu \mathrm{m}$, Mastermet Buehler, UK). Following polishing, the samples were cleaned in $1 \%$ Triton solution for $1 \mathrm{~h}$ and rinsed in deionised distilled water. This treatment was used as a control (C). The practice for surface preparation of surgical implants involves a nitric acid passivation treatment $(\mathrm{P})$ based on the ASTM F86 protocol using $30 \%$ nitric acid for $1 \mathrm{~h}$ [10]. A third treatment (the ageing treatment, A) consisted of the passivated treatment followed by ageing in boiling deionised distilled water for $10 \mathrm{~h}$. The successive steps of the three surface treatments are shown in Table 1. Finally, the discs were rinsed several times with sterile, endotoxin-free PBS before cells were seeded. As preliminary experiments, the endotoxin assay using Limulus Amebocyte Lysate (BioWhittaker, Emerainville, France) revealed that no contamination of lipopolysaccharides (LPS) was present on the surface of the treated samples.

\subsection{Cell culture}

Two human osteoblast-like cell lines obtained from American Tissue Culture Collection (Manassas, VA, USA) were tested: an immature osteoblast (MG-63) and a mature osteoblast (SaOS-2) [11]. Two cell lines were used as it has been shown that cellular response depends on the local environment as well as on cell state of maturation [12]. The osteoblasts were cultured in Dulbecco's modified Eagle's medium (DMEM) (Sigma, Buchs, Switzerland) containing $10 \%$ fetal bovine serum (Sigma), $1 \%$ PSF $(100 \times, 10,000 \mathrm{U} / \mathrm{ml}$ Penicillin, $10,000 \mu \mathrm{g} / \mathrm{ml}$ Streptomycin and $25 \mu \mathrm{g} / \mathrm{ml}$ Fungizone $^{\circledR}$ ) (GibcoBRL, Life Technologies, Basel, Switzerland) under a humidified $5 \% \mathrm{CO}_{2}$ air atmosphere at $37^{\circ} \mathrm{C}$.

MG-63 cells were seeded: (1) at a concentration of 5000 cells/well on $4 \mathrm{~mm}^{2}$ samples $(\mathrm{C}, \mathrm{P}, \mathrm{A})$ for cell proliferation assessment in 96 well cell culture plates;

Table 1

The successive steps of surface treatments for the control (C), the passivated $(\mathrm{P})$ and the aged $(\mathrm{A}) \mathrm{Ti}-6 \mathrm{Al}-4 \mathrm{~V}$ surfaces

\begin{tabular}{llll}
\hline & Control $(\mathrm{C})$ & Passivated $(\mathrm{P})$ & Aged (A) \\
\hline Surface preparation & Polished & Polished & Polished \\
& Cleaning in 1\% Triton for $1 \mathrm{~h}$ & Cleaning in $1 \%$ Triton for $1 \mathrm{~h}$ & Cleaning in $1 \%$ Triton for $1 \mathrm{~h}$ \\
& Rinsing in deionised distilled water & Rinsing in deionised distilled water & Rinsing in deionised distilled water \\
& & $30 \%$ nitric acid for $1 \mathrm{~h}$ & $30 \%$ nitric acid for $1 \mathrm{~h}$ \\
& Rinsing in deionised distilled water & Rinsing in deionised distilled water \\
& & & $10 \mathrm{~h}$ in boiling deionised distilled water
\end{tabular}

Sterilisation Immersed in $100 \%$ ethanol for $10 \mathrm{~min}$

Air-dried

Exposed under UV light for $30 \mathrm{~min}$ on each side

Rinsing in endotoxin free phosphate buffered solution (PBS) 
(2) at a concentration of 100,000 cells/well on $10 \mathrm{~mm}^{2}$ samples $(\mathrm{C}, \mathrm{P}, \mathrm{A})$ for cell viability assessment in 24 well cell culture. Proliferation and viability measurements were performed at 12, 24 and $72 \mathrm{~h}$. SaOS-2 cells were seeded at a concentration of 100,000 cells/well on $10 \mathrm{~mm}^{2}$ samples (C, P, A) for quantification of osteonectin, osteopontin, osteocalcin gene expression at week 1 and ALP activity, FN and TP at week 1, 2, 3 and 4 . The medium was changed every 3-4 days. For ALP, FN and TP measurements, the medium was removed two days before each time point (at week 1, 2, 3 and 4) and cells were washed 3 times with PBS to avoid the effects of serum composition on the biochemical assays. The cell culture was then incubated with serum free medium 2 days before biochemical assays.

\subsection{Cell viability/proliferation}

To assay cell viability, cells were collected by trypsinisation with $1 \times$ trypsin-EDTA solution (Sigma) $5 \mathrm{~min}$. The collected cells were double stained with $25 \mu \mathrm{g} / \mathrm{ml}$ fluorescein diacetate (Sigma) and with $20 \mu \mathrm{g} / \mathrm{ml}$ propidium iodide (Sigma) in PBS for $5 \mathrm{~min}$ [13]. Live cells appear green and dead cells appeared red under epifluorescent illumination (blue filter of $450-490 \mathrm{~nm}$ and green filter of $510-560 \mathrm{~nm}$ which allowed visualisation of the green and red fluorescing cell, respectively). Cell viability tests were performed three times for each point and at least 200 cells were counted in the epifluorescent mode of a Nikon Microphot-FXA microscope (Nikon, Tokyo, Japan). Cell viability was defined as the ratio of viable cells to the total number of cells and presented in percentage $(\%)$ for the treatments $(\mathrm{C}, \mathrm{P}, \mathrm{A})$. To assay cell proliferation, cells were treated with CellTiter $96^{\circledR} \mathrm{AQ}_{\text {ueous }}$ Assay (Promega Corp., WI, USA). The assay is based on the reduction of a tetrazolium compound to a coloured formazan product by viable cells (or metabolic activity). The absorbance at $490 \mathrm{~nm}$ is directly proportional to the cell proliferation. The cell proliferation of the passivated (P) and the aged (A) samples was normalised by the control (C).

\subsection{Osteonectin, osteopontin, osteocalcin gene expression}

Cell lysate was collected after week 1 and total RNA was isolated and purified with RNeasy columns (Qiagen, Basel). The isolated RNA was reversed transcripted to cDNA with the StratScript enzyme (Stratagene, San Diego, CA). Quantitative real time RT-PCR (TaqMan ABI Prism 7700, Applied Biosystem, Foster City, CA) was used to measure the gene expression of osteonectin, osteopontin, osteocalcin, and 18S using Amplifluor Universal Detection System (Intergen, Purchase, NY). Primers were designed with the Software Primer
Express $^{\text {TM }}$ (Applied Biosystem). Primers were purchased from Integrated DNA Technologies (Coralville, IA). Use of a housekeeping gene (18S) allowed the different samples to be normalized and compared between experiments.

\subsection{Total protein}

A solution of $0.5 \mathrm{ml} 1 \%$ Triton-X in MilliQ water was used to lyse cells. The lysate was sonicated for $30 \mathrm{~s}$ at $40 \mathrm{~W}$. The total protein amount was measured in the cell lysate with DC (Detergent Compatible) Protein Assay Kit (Bio-Rad Lab, CA, USA).

\subsection{Alkaline phosphatase activity}

ALP activity is considered to reflect osteoblastic activity and is thought to play a major role in bone formation and mineralisation [14]. The enzyme activity within the lysate was measured with a commercial Kit (Sigma ALP-10, cat. no.245). One unit of LPA activity is defined as that amount of enzyme, which produces $1 \mu \mathrm{mol}$ of $p$-nitrophenol (PNP)/min. The total protein amount was used to normalise the ALP activity.

\subsection{Fibronectin measurement}

FN is one of the most abundant extracellular matrix components in many tissues and has been shown to be present in early bone formation [15]. A commercially available Human Fibronectin ELISA kit (Biomedical Tech Inc., Stoughton, MA, USA) was used to measure FN within the lysate. The FN production was normalised by the total protein amount.

\subsection{Statistical analysis}

The viability and proliferation of MG-63 are presented at each time point $(12,24$, and $72 \mathrm{~h}$ ) corresponding to the mean \pm standard error of three independent analyses. Gene expression results of SaOS-2 are presented at week 1 and corresponded to the mean \pm standard error of three independent analyses performed in duplicates. The ALP activity and FN normalised by $\mathrm{TP}$ of SaOS-2 are presented at each time point $(1,2,3$ and 4 weeks) corresponding to the mean \pm standard error of four independent analyses performed in duplicates. ANOVA was used to determine the statistical significance of the differences observed between groups. $p$ values smaller than 0.05 were considered significant.

\subsection{Cell morphology}

Cell morphology studies can provide information concerning the cell interaction with the treated 
Ti-6Al-4V implant and cell-cell contact. SaOS-2 cells were seeded on to each sample $\left(10 \mathrm{~mm}^{2}\right)$ at a concentration of 2000 cells/well in 24-well tissue culture plates for $24 \mathrm{~h}$ and 7 days. Cells were then fixed with $1 \%$ glutaraldehyde (Sigma) in PBS, treated with $1 \%$ Triton $\mathrm{X}, 2 \mathrm{mg} / \mathrm{ml}$ sodium borohydride (Sigma) in PBS and stained with $4 \mu \mathrm{g} / \mathrm{ml}$ rhodamin-phalloidin (Sigma) for actin microfilaments. A Nikon Eclipse TE300 inverted epifluorescence microscope enabled cells to be visualised. A Standard filter set $(510 \mathrm{~nm})$ was used for rhodamin-phalloidin. Images were acquired with a Micromax PB1300 cooled CCD camera (Roper Scientific, Trenton, NJ) and image contrast enhancing was performed using a MetaMorph imaging system (Universal Imaging Corporation, Westchester, PA). The cell morphology and particularly the actin filament organisation were visually examined.

\section{Results}

\subsection{Cell viability/proliferation}

There was no significant difference between the three different treated samples for the cell viability of MG-63 during the test (Fig. 1). The aged sample had higher cell proliferation compared to the passivated samples at $72 \mathrm{~h}$ (Fig. 2).

\subsection{Osteonectin, osteopontin, osteocalcin gene expression}

There was no significant difference between the three different treated samples for the osteonectin, osteopontin, and osteocalcin gene expression of SaOS-2 at week 1 (Fig. 3). The level of gene expression was comparable

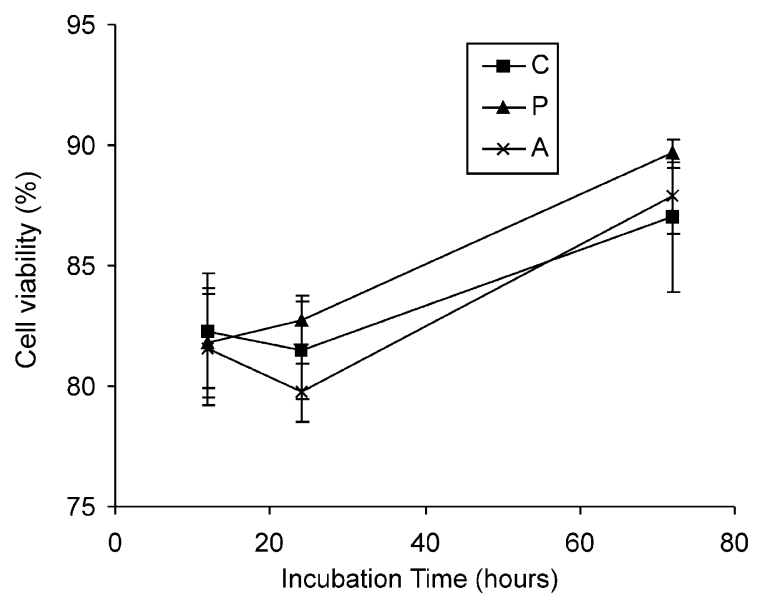

Fig. 1. Viability of MG-63 cells on the different Ti-6Al-4V samples. There was no significant difference between the three different treated samples (C: control, P: passivated; A: aged) for the MG-63 cell viability at 12,24 , and $72 \mathrm{~h}$. for osteonectin and osteopontin for each sample while higher level was found for osteocalcin of MG-63 during the test (Fig. 1).

\subsection{Alkaline phosphatase activity}

The ALP activity of the control sample was statistically higher than the passivated and the aged samples at week 2 (Fig. 4). At week 4, the aged sample induced a statistically higher ALP activity than the passivated and the control samples.

\subsection{Fibronectin measurement}

No FN activity was detected at week 1 (Fig. 5). FN activity was observed after week 2 and reached a peak at

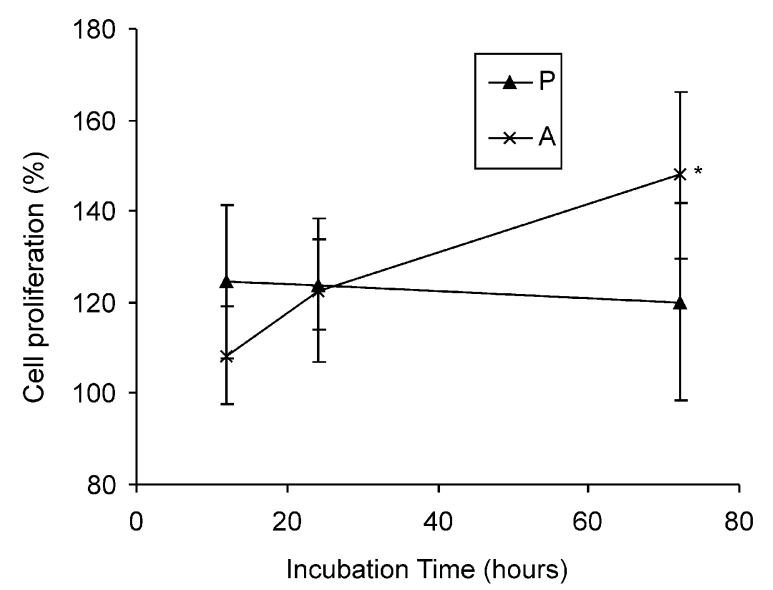

Fig. 2. Proliferation of MG-63 cells on the different Ti-6Al-4V samples. The proliferation of $\mathrm{P}$ and $\mathrm{A}$ was normalised by the proliferation of C. A significant difference between the aged and passivated samples was found at $72 \mathrm{~h}(*: p \leqslant 0.05$; P: passivated; A: aged).

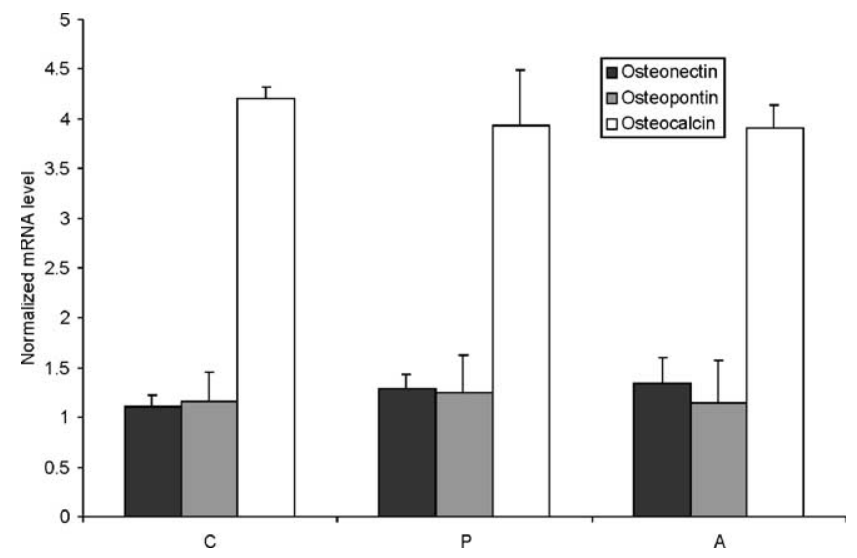

Fig. 3. Gene expression of osteonectin, osteopontin, and osteocalcin normalised by the gene expression of $18 \mathrm{~S}$ on the different $\mathrm{Ti}-6 \mathrm{Al}-4 \mathrm{~V}$ samples. There was no significant difference between the three different treated samples (C: control, P: passivated; A: aged) for the SaOS-2 cells gene expression at week 1 . 
week 3 before decreasing at week 4 . There was no significant difference among the three surface treatments.

\subsection{Cell morphology}

After $24 \mathrm{~h}$, bundles of actin filaments (stress fibres) were found and cells had an angular shape on the three different treated surfaces. Focal adhesion and some small stress fibres were also visible at the cells periphery (Fig. 6). After 7 days, cell-cell contact was visualised for the osteoblasts on these three surface treatments. No major difference was visually found between the three surface treatments.

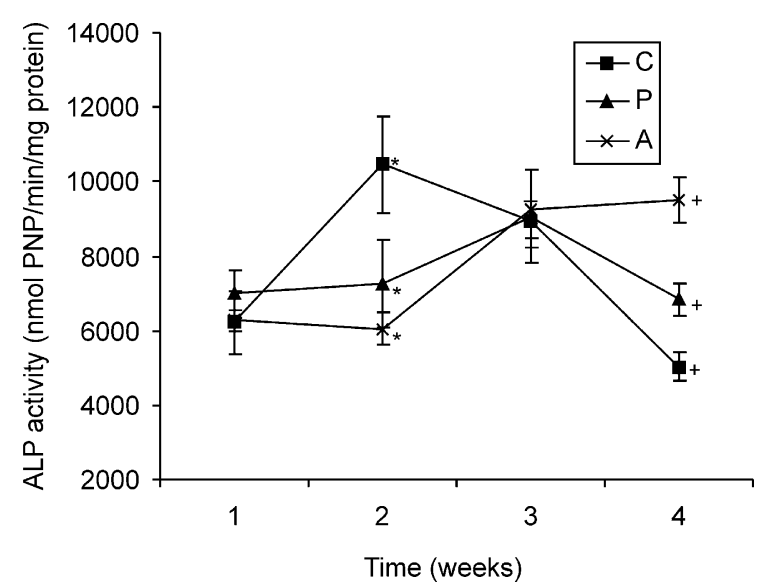

Fig. 4. ALP activity of SaOS-2 cells on the treated Ti-6Al-4V samples (C: control, P: passivated, A: aged). At week 2, there was a significant difference between $\mathrm{C}$ versus $\mathrm{P}$ and between $\mathrm{C}$ versus $\mathrm{A}(*: p \leqslant 0.05)$. At week 4 , there was a significant difference between $\mathrm{C}$ versus $\mathrm{A}$ and between $\mathrm{P}$ versus $\mathrm{A}(+: p \leqslant 0.05)$.

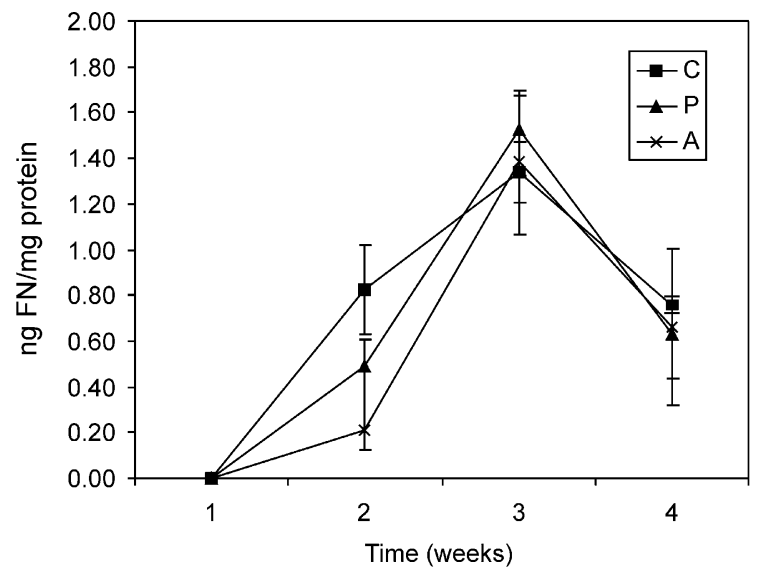

Fig. 5. Fibronectin measurements of SaOS-2 cells on the different $\mathrm{Ti}-$ 6Al-4V samples. No fibronectin was detected for all samples at week 1 . There was no significant difference between the three different treated samples (C: control, P: passivated; A: aged) for the SaOS-2 cells fibronectin production at week 2,3 , and 4 .

\section{Discussion}

In short-term in vitro tests $(24 \mathrm{~h})$, cell viability/ proliferation and cell morphology demonstrated no evidence of cell toxicity in response to the different treated Ti-6Al-4V surfaces. Moreover, the cell morphology of SaOS-2 clearly showed that focal adhesion sites localised at the periphery and bundles of actin filaments spanned the entire cells when cells were seeded on the three different samples (Fig. 6). Based on these results, it was not possible to discriminate the effects of the different surface treatments on oseteoblasts behaviour.

Differences between osteoblasts behaviour became apparent only since $72 \mathrm{~h}$ with a significant difference in proliferation between the aged and the passivated samples (Fig. 2). The proliferation measurement was based on cellular reduction of MTS and was dependent on the reduced pyridine nucleotides NADH and $\mathrm{NADPH}$, i.e. finally on mitochondrial activity. The cellular damage in mitochondria inevitably results in loss of the ability of the cell to maintain and provide energy for metabolic cell function and growth [16]. Decrease in cell proliferation suggests that metal ion release may indeed affect mitochondrial activity. Nevertheless, this hypothesis needs to be further confirmed.

It has been found that by affecting their proliferation, osteoblasts may delay the time course of their differentiation stages e.g. [17]. In the present study, we showed that metal ion release from the different surface treatments affected the cell proliferation. Therefore, it seems reasonable to assume that the different surface treatments may shift the time course of differentiation stage. A delay in the peak measurement of ALP activity was noted on the aged and the passivated samples compared to the control sample (Fig. 4). Even though results comparisons between two different cell lines should be handled carefully, it seems that the decrease of MG-63 proliferation and the delay in the peak measurement of SaOS-2 ALP activity agrees with the assumption mentioned that surface treatment could delay the differentiation pathway of the osteoblasts. A similar result has been demonstrated in a previous study [18].

The osteocalcin, osteopontin and osteonectin are important osteoblastic markers and are expressed at different maturation stages of the osteoblasts [19]. These three genes have been shown to be differently involved in the bone mineralization process. Osteocalcin, which is the most osteoblast-specific gene yet known [20], has been demonstrated to stimulate bone mineral maturation [21]. Osteopontin has been shown to inhibit the crystal growth of hydroxyapatite e.g. [22], while osteonectin has been suggested to promote collagen mineralization [23]. In the present study, no difference in 

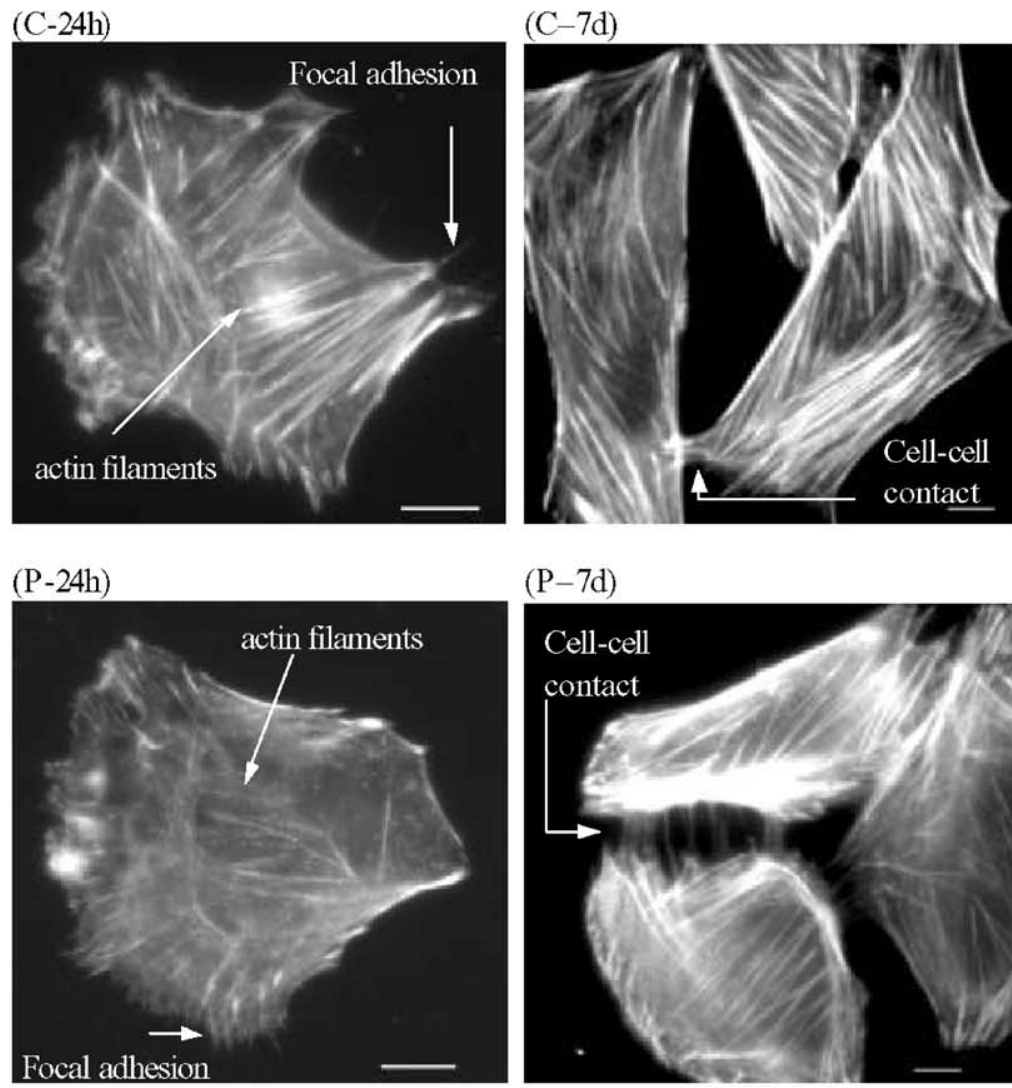

$(\mathrm{P}-7 \mathrm{~d})$
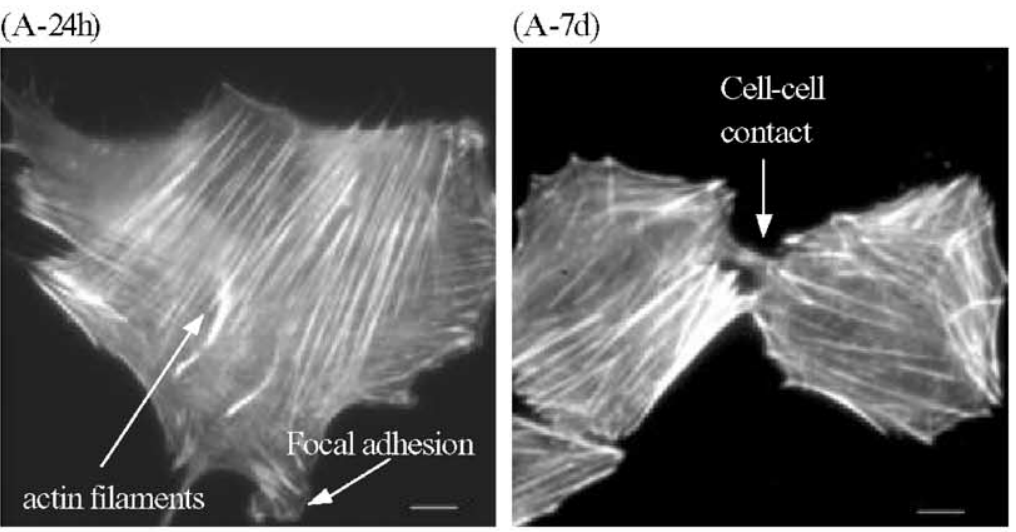

Fig. 6. Morphology of SaOS-2 cells seeded on the different Ti-6Al-4 V samples at $24 \mathrm{~h}$ (C-24 h, P-24 h, A-24h) and 7 days (C-7 d, P-7 d, A-7 d) (C: control, P: passivated; A: aged). Actin filaments and focal adhesion points were clearly visible at $24 \mathrm{~h}$.

osteocalcin, osteopontin and osteonectin gene expression was found at week 1 between the samples. The different surface treatments seen then not to induce a different mineralization process, at least during the first week.

No FN was detected at week 1 . Other proteins such as collagen may play a major role in the cell attachment to the different samples instead of FN at week 1 e.g. [24]. It may also be possible that the metal ion release from the samples affected the initial production of FN. A previous study has demonstrated that FN was not involved in the adhesion of osteoblasts to uncoated $\mathrm{Ti}$ alloy at $24 \mathrm{~h}$ [25]. Moreover, the integrin $\alpha_{5}-$ which is a major adhesion receptor of osteoblasts interacting with FN [26,27] - was not detected in cell cultured on polished or rough $\mathrm{Ti}-6 \mathrm{~A} 1-4 \mathrm{~V}$ at $12 \mathrm{~h}$ while it was detected for cell cultured on polystyrene [28]. Despite results of the study by Sinha and Tuan [28] were obtained at $12 \mathrm{~h}$ while present $\mathrm{FN}$ results were obtained at week 1, they could support the hypothesis that proteins other than FN were involved in the osteoblast adhesion to $\mathrm{Ti}$ alloy. The production of $\mathrm{FN}$ observed 
after two weeks could then probably be due to cell-cell contact e.g. [29]. The increasing FN production at week 2 and 3 could also contribute to cell spreading configuration maintaining the survival of mature osteoblasts [30].

Previous work in our group has demonstrated that the different surface treatments alter the metal ion release kinetics and surface composition of the Ti-6A1-4V alloy [9,31]. The release of A1 ions was found to be about $0.84 \mu \mathrm{M}$ for the ageing treatment and about $5.55 \mu \mathrm{M}$ for the passivation treatment after 7 days [9]. The osteoblasts cultured on the aged surface experienced therefore, a much lower concentration of A1 ions during the test duration. The kinetics of the metal ion dissolution, especially for A1, could then explain the differences in cell behaviour, which were observed only in long-term in vitro study. Indeed, results of ALP peak activity at week 2 for the control treatment compared to the passivated and aged treatments was in agreement with a previous study using a similar A1 ion concentration [32]. It should be noted also that the only difference in terms of ion release composition between the different Ti-6A1-4V surface treatments was the presence of vanadium for the control treatment. It may be possible therefore, that vanadium also has an impact on osteoblast differentiation by maturing the osteoblasts faster. Further experiments on this particular hypothesis need to be performed before a definitive conclusion can be drawn.

It has been shown that surface roughness influenced the cell behaviour [12]. We have used XPS and AFM techniques to examine the surface properties of the treated Ti-6Al-4V surfaces [33]. A difference in roughness $\left(R_{\mathrm{a}}\right)$ between the passivated and the aged samples could only be observed at a small scale $\left(1 \mu \mathrm{m}^{2}\right)$. The area average $R_{\mathrm{a}}$ was about $0.99 \mathrm{~nm}(\mathrm{C}), 1.29 \mathrm{~nm}(\mathrm{P})$ and $0.56 \mathrm{~nm}$ (A). Therefore, at the cell level, the roughness could be considered as similar between samples and could not explain the differences in osteoblasts behaviour.

Biocompatibility tests such as those performed in this study can only quantify particular aspects of cell behaviour. The cell reaction to an implant is however a very complex situation and can only be partially understood using standard biological assays. In order to have a comprehensive description of the cell-implant interaction with surface treated $\mathrm{Ti}$ alloy, cDNA microarray technology may be performed e.g. $[34,35]$. This represents the next step of this study.

\section{Conclusions}

In this study, short-term $(24 \mathrm{~h})$ in vitro experiments demonstrated that different $\mathrm{Ti}-6 \mathrm{Al}-4 \mathrm{~V}$ surface treat- ments had negligible effects on the measured parameters. Cell viability remained unaffected and cell morphology expressed rich actin filaments. In longer in vitro experiments (from $72 \mathrm{~h}$ until 4 weeks), the difference in the kinetics of metal ion dissolution between treatments is more important and consequently a higher cell proliferation on the aged sample and an accelerated peak of ALP activity on the control sample were observed. Osteonectin, osteopontin, and osteocalcin gene expression (at week 1) as well as FN production (until week 4) were not affected by the different surface treatments. Based on our previous metal ion release studies and surface analyses, A1 ions release kinetics as well as presence of vanadium ions may play a major role in influencing the osteoblasts behaviour in the present study.

\section{Acknowledgements}

The financial support of the Bioengineering Sciences Research group of the School of Engineering Sciences at University of Southampton and the Orthopaedic Hospital of Lausanne and the Biomedical Engineering Laboratory at the EPFL is gratefully acknowledged. The authors would like to thank Dr. A. Verkhovsky at the Biomedical Engineering Laboratory for his advice and assistance with cell morphology study.

\section{References}

[1] Nanci A, Wuest JD, Peru L, Brunet P, Sharma V, Zalzal S, McKee MD. Chemical modification of titanium surfaces for covalent attachment of biological molecules. J Biomed Mater Res 1998;40:324-35.

[2] Ratner BD. Molecular design strategies for biomaterials that heal. Macromol Symp 1998;130:327-35.

[3] Williams DF. Titanium and titanium alloys. Boca Raton, FL: CRC Press, 1981.

[4] Callen BW, Sodhi RN, Griffiths K. Examination of clinical surface preparations on titanium and $\mathrm{Ti}-6 \mathrm{Al}-4 \mathrm{~V}$ by $\mathrm{X}$-ray photoelectron spectroscopy and nuclear reaction analysis. Progr Surf Sci 1995;50:269-79.

[5] Amstutz HC, Campbell P, McKellop H, Schmalzreid TP, Gillespie WJ, Howie D, Jacobs J, Medley J, Merritt K. Metal on metal total hip replacement workshop consensus document. Clin Orthop 1996;329:S297-303.

[6] Jacobs JJ, Skipor AK, Black J, Urban R, Galante JO. Release and excretion of metal in patients who have a total hip-replacement component made of titanium-base alloy [see comments]. J Bone Jt Surg [Am] 1991;73:1475-86.

[7] Liao H, Wurtz T, Li J. Influence of titanium ion on mineral formation and properties of osteoid nodules in rat calvaria cultures. J Biomed Mater Res 1999;47:220-7.

[8] Thompson GJ, Puleo DA. Ti-6Al-4V ion solution inhibition of osteogenic cell phenotype as a function of differentiation timecourse in vitro. Biomaterials 1996;17:1949-54. 
[9] Browne M, Gregson PJ, West RH. Characterization of titanium alloy implant surfaces with improved dissolution resistance. J Mater Sci Mater Med 1996;7:323-9.

[10] ASTM. Medical devices; Emergency medical services. Pennsylvania, USA. American Society for Testing and Materials, 1999.

[11] Ahmad M, McCarthy M, Gronowicz G. An in vitro model for mineralization of human osteoblast-like cells on implant materials. Biomaterials 1999;20:211-20.

[12] Boyan BD, Hummert TW, Kieswetter K, Schraub D, Dean DD, Schwartz Z. Effect of titanium surface characteristics on chondrocytes and osteoblasts in vitro. Cells Mater 1995;5:323-34.

[13] Jones KH, Senft JA. An improved method to determine cell viability by simultaneous staining with fluorescein diacetatepropidium iodide. J Histochem Cytochem 1985;33:77-9.

[14] Laitinen M, Halttunen T, Jortikka L, Teronen O, Sorsa T, Lindholm TS. The role of transforming growth factor-beta on retarded osteoblastic differentiation in vitro. Life Sci 1999;64: $847-58$.

[15] Cowles EA, DeRome ME, Pastizzo G, Brailey LL, Gronowicz GA. Mineralization and the expression of matrix proteins during in vivo bone development. Calcif Tissue Int 1998;62:74-82.

[16] Kowaltowski AJ, Castilho RF, Vercesi AE. Mitochondrial permeability transition and oxidative stress. Febs Lett 2001; 495:12-5.

[17] Noda M. Cellular and molecular biology of bone. San Diego: Academic Press, 1993.

[18] Stein GS, Lian JB. Molecular mechanisms mediating proliferation/differentiation interrelationships during progressive development of the osteoblast phenotype. Endocr Rev 1993;14:424-42.

[19] Lian JB, Stein GS. Osteoblast biology. R. Marcus, D. Feldman, J. Kelsey. San Diego: Academic Press, 1996.

[20] Ducy P, Karsenty G. Genetic control of cell differentiation in the skeleton. Curr Opinion Cell Biol 1998;10:614-9.

[21] Boskey AL, Gadaleta S, Gundberg C, Doty SB, Ducy P, Karsenty G. Fourier transform infrared microspectroscopic analysis of bones of osteocalcin-deficient mice provides insight into the function of osteocalcin. Bone 1998;23:187-96.

[22] Ayukawa Y, Takeshita F, Inoue T, Yoshinari M, Shimono M, Suetsugu T, Tanaka T. An immunoelectron microscopic localiza- tion of noncollagenous bone proteins (osteocalcin and osteopontin) at the bone-titanium interface of rat tibiae. J Biomed Mater Res 1998;41:111-9.

[23] Termine JD, Kleinman HK, Whitson SW, Conn KM, McGarvey ML, Martin GR. Osteonectin, a bone-specific protein linking mineral to collagen. Cell 1981;26:99-105.

[24] Gronowicz G, McCarthy MB. Response of human osteoblasts to implant materials: integrin-mediated adhesion. J Orthop Res 1996;14:878-87.

[25] Geissler U, Hempel U, Wolf C, Scharnweber D, Worch H, Wenzel K. Collagen type I-coating of $\mathrm{Ti}-6 \mathrm{Al}-4 \mathrm{~V}$ promotes adhesion of osteoblasts. J Biomed Mater Res 2000;51:752-60.

[26] Schneider G, Burridge K. Formation of focal adhesions by osteoblasts adhering to different substrata. Exp Cell Res 1994; 214:264-9.

[27] Webster TJ, Ergun C, Doremus RH, Siegel RW, Bizios R. Specific proteins mediate enhanced osteoblast adhesion on nanophase ceramics. J Biomed Mater Res 2000;51:475-83.

[28] Sinha RK, Tuan RS. Regulation of human osteoblast integrin expression by orthopaedic implant materials. Bone 1996;18:451-7.

[29] Hynes RO. Cell adhesion: old and new questions. Trends Cell Biol 1999;9:M33-7.

[30] Chen CS, Mrksich M, Huang S, Whitesides GM, Ingber DE. Geometric control of cell life and death. Science 1997;276: 1425-8.

[31] Browne M, Gregson PJ. Surface modification of titanium alloy implants. Biomaterials 1994;15:894-8.

[32] Bellows CG, Heersche JN, Aubin JE. Aluminium accelerates osteoblastic differentiation but is cytotoxic in long-term rat calvaria cell cultures. Calcif Tissue Int 1999;65:59-65.

[33] $\mathrm{Ku} \mathrm{C}-\mathrm{H}$, Browne M, Gregson PJ. Examination of the surface properties of the different treated $\mathrm{Ti}-6 \mathrm{Al}-4 \mathrm{~V}$ alloy 2001 , to be submitted to Biomaterials.

[34] Pioletti DP, Leoni L, Genini D, Takei H, Du P, Corbeil J. Osteoblast-particle interaction: a functional genomic description. Proceedings of the 10th EORS, 2000. p. 16.

[35] Pioletti DP, Leoni L, Genini D, Takei H, Du P, Corbeil J. Gene expression analysis of osteoblastic cells contacted by orthopedic implant particles. J Biomed Mat Res, in revision. 